\title{
Non-biased enrichment does not improve quantitative proteomic delineation of reovirus T3D-infected HeLa cell protein alterations
}

\author{
Jieyuan Jiang ${ }^{1 \dagger}{ }^{\dagger}$ Kolawole J. Opanubi ${ }^{1}$ and Kevin M. Coombs ${ }^{1,2,3 *}$ \\ ${ }^{1}$ Department of Medical Microbiology, Faculty of Medicine, University of Manitoba, Winnipeg, MB, Canada \\ ${ }^{2}$ Manitoba Center for Proteomics and Systems Biology, University of Manitoba, Winnipeg, MB, Canada \\ ${ }^{3}$ Manitoba Institute of Child Health, University of Manitoba, Winnipeg, MB, Canada
}

\section{Edited by:}

Ben Berkhout, University of Amsterdam, Netherlands

Reviewed by:

Hendrik Huthoff, King's College

London, UK

Dave Speijer, University of

Amsterdam, Netherlands

*Correspondence:

Kevin M. Coombs, Manitoba Centre

for Proteomics and Systems Biology, John Buhler Research Centre, Room 799, 715 McDermot Avenue, Winnipeg, MB, Canada R3E 3P4.

e-mail:kcoombs@cc.umanitoba.ca

\section{${ }^{+}$Present address:}

Jieyuan Jiang, Institute of Veterinary Medicine, Jiangsu Academy of

Agricultural Sciences, Nanjing 210014, China.

\begin{abstract}
Mass spectrometry-based methods have allowed elucidation of alterations in complex proteomes, such as eukaryotic cells. Such studies have identified and measured relative abundances of thousands of host proteins after cells are infected with a virus. One of the potential limitations in such studies is that generally only the most abundant proteins are identified, leaving the deep richness of the cellular proteome largely unexplored. We differentially labeled HeLa cells with light and heavy stable isotopic forms of lysine and arginine and infected cells with reovirus strain T3D. Cells were harvested at $24 \mathrm{~h}$ postinfection. Heavy-labeled infected and light-labeled mock-infected cells were mixed together 1:1. Cells were then divided into cytosol and nuclear fractions and each fraction analyzed, both by standard 2D-HPLC/MS, and also after each fraction had been reacted with a random hexapeptide library (Proteominer ${ }^{\circledR}$ beads) to attempt to enrich for low-abundance cellular proteins. A total of 2,736 proteins were identified by two or more peptides at $>99 \%$ confidence, of which 66 were significantly up-regulated and 67 were significantly down-regulated. Up-regulated proteins included those involved in antimicrobial and antiviral responses, GTPase activity, nucleotide binding, interferon signaling, and enzymes associated with energy generation. Down-regulated proteins included those involved in cell and biological adhesion, regulation of cell proliferation, structural molecule activity, and numerous molecular binding activities. Comparisons of the $r^{2}$ correlations, degree of dataset overlap, and numbers of peptides detected suggest that non-biased enrichment approaches may not provide additional data to allow deeper quantitative and comparative mining of complex proteomes.
\end{abstract}

Keywords: RNA virus, virus infection, host cell alterations, mass spectrometry, liquid chromatography, bioinformatics

\section{INTRODUCTION}

The mammalian reoviruses (MRV) are non-enveloped viruses with genomes consisting of 10 segments of double-stranded RNA. MRV is the prototype member of the Orthoreovirus genus in the Reoviridae family and was first isolated in the respiratory and enteric tracts of healthy humans in the early 1950s. MRV infections are generally mild in humans. The Orthoreoviruses include non-fusogenic MRV and fusogenic avian reovirus. MRV consist of three serotypes. Each serotype has prototype strains: strain Lang (T1L) for serotype 1, strain Jones (T2J) for serotype 2, and strain Dearing (T3D) for serotype 3 (Tran and Coombs, 2006; Schiff et al., 2007). One of the most potentially useful characteristics of MRV is its ability to selectively kill certain cancer cells (Coffey et al., 1998; Forsyth et al., 2008; Thirukkumaran et al., 2010). An activated Ras pathway and functional p53 appear to be requirements for this selective oncolytic property (Coffey et al., 1998; Pan et al., 2011). Global analyses of oligonucleotide microarrays have detected activation of numerous cellular genes, including many related to apoptosis (Poggioli et al., 2002; DeBiasi et al., 2003).
However, global alterations in proteins (the effector molecules) after MRV infection have not yet been reported.

Except for certain epigenetic events (reviewed in Goldberg et al., 2007), a cell's genome generally remains relatively constant. However, the cell's proteome (the total protein repertoire, including all co-translational and post-translational modifications) varies greatly due to its biochemical interactions with the genome, as well as the cell's interactions with the environment. In the case of viruses, which require the host cell's machinery and metabolism to replicate, the cell's proteome also reflects the specific alterations of the pathways induced by virus infection.

Previous analyses of how cells respond to virus infection have used microarray technologies which measure the cellular "transcriptome" (see for example; Geiss et al., 2002; Kobasa et al., 2007). However, there frequently is little concordance between microarray and protein data (Tian et al., 2004; Baas et al., 2006), partly because mRNA levels cannot provide complete information about levels of protein synthesis or extents of post-translational modifications. Thus, proteomic analyses have also been employed 
to better understand host alterations induced by virus infection. These have included two-dimensional difference in gel electrophoresis (2D-DIGE; see for examples; Burgener et al., 2008; Lucitt et al., 2008), isotope coded affinity tags (ICAT; Booy et al., 2005; Stewart et al., 2006), isobaric tags for relative and absolute quantitation (iTRAQ; Dwivedi et al., 2009; Zhang et al., 2009), and stable isotope labeling by amino acids in cell culture (SILAC; Skiba et al., 2008). We have previously used SILAC to measure proteomic alterations in influenza virus-infected A549 cells (Coombs et al., 2010). Cells were labeled with either ${ }^{12} \mathrm{C}_{6}$-Lys and ${ }^{12} \mathrm{C}_{6}{ }^{14} \mathrm{~N}_{4}$-Arg ("light"; L), or ${ }^{13} \mathrm{C}_{6}$-Lys and ${ }^{13} \mathrm{C}_{6}{ }^{15} \mathrm{~N}_{4}$-Arg ("heavy"; $\mathbf{H}$ ), because virtually every tryptic peptide is expected to contain an $\mathbf{L}$ or $\mathbf{H}$ label, thereby providing increased protein coverage. In addition, $\mathbf{L}$ and $\mathbf{H}$ samples are mixed together early in this process, thereby reducing sample-to-sample variability.

Most quantitative proteomic analyses succeed in identifying and measuring several 1,000 proteins. Head-to-head comparisons suggest SILAC identifies more proteins than other methods (reviewed in Coombs, 2011); however, the 3,000-5,000 identified in many such studies still represents a small fraction of the estimated entire eukaryotic proteome. It is generally assumed that high-abundance proteins are most easily detected and lowabundance proteins masked by other components (Zolotarjova et al., 2008). Some studies have attempted to deplete highabundance proteins (for example Dwivedi et al., 2009) or to use methods to enrich for selected proteins (Jiang et al., 2007). Both of these methods potentially suffer from selective bias for specific proteins. We decided to attempt to enrich for low-abundance proteins by using Proteominer ${ }^{\mathrm{TM}}$ (PM) beads (Bio-rad), which consist of a "library" of 64 million random hexapeptides to non-selectively bind interacting partners. We succeeded in the current study in identifying and measuring 2,736 host proteins. Sixty six proteins were significantly up-regulated, including those involved in antimicrobial and antiviral responses, GTPase activity, nucleotide binding, interferon signaling, and enzymes associated with energy generation. Sixty seven proteins, including those involved in cell and biological adhesion, regulation of cell proliferation, structural molecule activity, and numerous molecular binding activities were significantly down-regulated. However, comparison of the numbers of proteins identified with or without PM enrichment suggests this type of non-biased enrichment may not contribute substantially to deeper proteomic elucidation.

\section{MATERIALS AND METHODS CELLS AND VIRUSES \\ Cell lines}

Spinner-adapted mouse fibroblast L929 cells (L929) were grown in Joklik's modified minimal essential medium (J-MEM; Gibco, Grand Island, NY, USA) supplemented with 6\% fetal bovine serum (FBS; Hyclone, Rockford, IL, USA), and $2 \mathrm{mM}$ L-glutamine as described (Berard and Coombs, 2009). Reovirus was grown according to standard lab practice (Berard and Coombs, 2009).

Human HeLa cells were routinely cultured in Dulbecco's modified MEM (DMEM) supplemented with non-essential amino acids, sodium pyruvate, $0.2 \%(\mathrm{w} / \mathrm{v})$ glucose, $10 \%$ FBS (Hyclone), and $2 \mathrm{mM} \mathrm{L}$-glutamine. Cells were maintained as monolayers in $5 \% \mathrm{CO}_{2}$ and were passaged by trypsinization 2-3 times each week.
For SILAC labeling, cells were grown in DMEM media provided with a SILAC ${ }^{\mathrm{TM}}$ Phosphoprotein Identification and Quantification Kit (Invitrogen Canada Inc., Burlington, ON, Canada), supplemented as above (except without non-essential amino acids), and with 10\% dialyzed FBS (Invitrogen Canada Inc.), plus $100 \mathrm{mg}$ each of "light" (L) or "heavy" (H) L-lysine and L-arginine per liter of DMEM.

\section{Viruses}

Reovirus strain Type 3 Dearing (T3D) is a laboratory stock. Virus amplifications were routinely performed in L929 cell monolayers grown in the presence of $5 \% \mathrm{CO}_{2}$ at $37^{\circ} \mathrm{C}$, supplemented with J-MEM as described above, except with $3 \%$ FBS instead of $6 \%$ FBS in the cell culture media, $100 \mathrm{U} / \mathrm{ml}$ of penicillin, $100 \mu \mathrm{g} / \mathrm{ml}$ streptomycin sulfate, and $100 \mu \mathrm{g} / \mathrm{ml}$ amphotericin-B as previously described (Berard and Coombs, 2009).

\section{Virus purification}

Large amounts of reovirus T3D were grown in 11 suspension L929 cell cultures and purified by routine procedures involving Vertrel$\mathrm{XF}^{\mathrm{TM}}$ extraction and cesium chloride $(\mathrm{CsCl})$ ultracentrifugation (Mendez et al., 2000). Purified virions were then dialyzed against D-Buffer (150 mM NaCl, $15 \mathrm{mM} \mathrm{MgCl}_{2}, 10 \mathrm{mM}$ Tris, $\mathrm{pH}$ 7.4). Virus concentration was measured by optical density at $260 \mathrm{~nm}$, using the relationship $1 \mathrm{ODU}=2.1 \times 10^{12}$ particles per milliliter (Smith et al., 1969) and infectivity was titrated.

\section{Virus titrations}

Serial 1:10 dilutions of virus samples were made in gel saline ( $137 \mathrm{mM} \mathrm{NaCl}, 0.2 \mathrm{mM} \mathrm{CaCl} 2,0.8 \mathrm{mM} \mathrm{MgCl} 2,19 \mathrm{mM} \mathrm{HBO}_{3}$, $0.1 \mathrm{mM} \mathrm{Na}_{2} \mathrm{~B}_{4} \mathrm{O}_{7}$, and $0.3 \% \mathrm{w} / \mathrm{v}$ gelatin). HeLa cell and L929 cell monolayers in six-well plates were infected in duplicate, viruses allowed to attach to cells for $1 \mathrm{~h}$ with periodic rocking, and each well overlaid with a 50:50 ratio of $2 \%$ agar and $2 \times$ Medium 199 (M199) supplemented with a final concentration of 3\% FBS, 2 mM L-glutamine, $100 \mathrm{U} / \mathrm{ml}$ of penicillin, $100 \mu \mathrm{g} / \mathrm{ml}$ streptomycin sulfate, and $100 \mu \mathrm{g} / \mathrm{ml}$ amphotericin-B. Plates were fed 3 days later with fresh agar/M199 and were stained with a $0.04 \%$ neutral red solution on day 6 . Viral plaques were counted $15-18 \mathrm{~h}$ later and titers calculated (Berard and Coombs, 2009).

\section{SILAC infection}

Once HeLa cells had grown through six doublings in appropriate SILAC media, $\mathbf{H}$ cells were infected with gradient-purified $\mathrm{T} 3 \mathrm{D}$ at a multiplicity of infection (MOI) of seven plaque forming units (PFU) per cell. An equivalent number of $\mathbf{L}$ cells were mock-infected with diluent as control. Cells were overlaid with appropriate media and cultured for $24 \mathrm{~h}$.

\section{CELL FRACTIONATION}

At 24hpi, $\mathbf{L}$ and $\mathbf{H}$ cells in the T75 flasks were collected and counted. To verify infection status of each culture, aliquots of all cultures were saved for virus titration. For comparative SILAC assays, equivalent numbers of $\mathbf{L}$ and $\mathbf{H}$ cells were mixed together, and the mixed cells were washed $3 \times$ in $>50$ volumes of ice-cold Phosphate Buffered Saline (PBS). Washed cells were lysed with $0.5 \%$ NP-40, supplemented with $1.1 \mu \mathrm{M}$ pepstatin A, incubated 
on ice for $30 \mathrm{~min}$, and nuclei removed by pelleting at $5,000 \times g$ for $10 \mathrm{~min}$. The cytosol and soluble membranes (supernatant) were transferred to a fresh microfuge tube; and the two fractions (nuclear pellet and supernatant) were frozen at $-80^{\circ} \mathrm{C}$ until further processing took place.

Thawed nuclei were extracted with one volume of High Salt Buffer (620 mM NaCl, $1 \mathrm{mM}$ DTT, $10 \mathrm{mM}$ Tris, pH 8.0), insoluble material pelleted at $15,000 \times g$ for $10 \mathrm{~min}$, and the supernatant removed and saved. Insoluble pellets were then extracted with $1 / 3$ rd volume of $8 \mathrm{M}$ urea, insoluble material pelleted as above, the two extractions combined, and samples stored at $-80^{\circ} \mathrm{C}$ until further processing took place.

\section{PROTEOMINER ${ }^{\text {TM }}$ PURIFICATION}

Approximately $90 \%$ of each fraction (cytosol and nucleus) was passed through separate PM Mini columns. The columns were processed according to manufacturer's protocol (Bio-Rad Corp). Briefly, the cytosolic and nuclear protein fractions were measured and each fraction concentrated to $\approx 20 \mathrm{mg} / \mathrm{ml}(\sim 1 \mathrm{ml})$. PM beads were washed twice with Wash Buffer then incubated with each concentrated protein sample for $2 \mathrm{~h}$ with end-to-end shaking. Columns were spun at $1,000 \times g$ for $2 \mathrm{~min}$ to remove excess fluid, washed $3 \times$ with Wash Buffer, and then bound proteins eluted with two sequential applications of $200 \mu$ l One-step Elution Buffer.

\section{WESTERN BLOTTING}

Western blot analyses of HeLa cells were performed essentially as described previously (Coombs et al., 2010). Briefly, unlabelled cells were harvested essentially as described above and cytosolic proteins were resolved on a $10 \%$ SDS-PAGE gel at $120 \mathrm{~V}$ for $70 \mathrm{~min}$. Proteins were transferred to polyvinylidenedifluoride (PVDF) membranes at $20 \mathrm{~V}$ for $30 \mathrm{~min}$ in a semi-dry apparatus, and the transfer confirmed by Ponceau staining. Membranes were blocked with 5\% skim milk in TBST and probed with various antibodies in 1\% BSA in TBST. Primary antibodies were: in-house rabbit anti-reovirus, $\alpha$-GAPDH (Cell Signaling, cat\#2118), $\alpha$-IFIT2 (Abcam, cat\#ab55837), and $\alpha$-SAMD9 (Sigma cat\#HPA021318), goat $\alpha-M x 1$ (Santa Cruz cat\#sc-34128), and mouse anti-STAT1 (Cell Signaling, cat\#9176), $\alpha$-Actin (Sigma, cat\#A5441). The secondary antibodies were the appropriate horseradish peroxidase (HRP)-conjugated rabbit anti-mouse or goat anti-rabbit (Cell Signaling, cat\#7076 and cat\#7074, respectively). Bands were detected by enhanced chemiluminescence using an Alpha Innotech FluorChem Q Multi Image III instrument.

\section{IMMUNOFLUORESCENT MICROSCOPY}

HeLa cells were grown overnight in a $37^{\circ} \mathrm{C}, 5 \% \mathrm{CO}_{2}$ incubator to $80 \%$ confluency on autoclaved 12 -spot slides and then infected with MRV T3D at a MOI of seven or mock-infected. Mock, 0, 6, 12 , and $24 \mathrm{~h}$ infected cells were washed $5 \times$ with PBS and fixed with $4 \%$ paraformaldehyde for $15 \mathrm{~min}$ at $4^{\circ} \mathrm{C}$. Cells were then washed $4 \times$ with $1 \times \mathrm{PBS}$ and kept in $1 \times \mathrm{PBS}$ at $4^{\circ} \mathrm{C}$ until the $24 \mathrm{~h}$ time point was collected. Cells from all time points were then permeabilized with $0.1 \%$ TritonX-100 in $1 \times$ PBS for 5 min at $4{ }^{\circ} \mathrm{C}$ followed by five washes with $1 \times$ PBS. Cells were blocked with $1 \%$ BSA in $1 \times$ PBS and then treated with primary antibody (in-house rabbit anti-reovirus). Cells were then washed $5 \times$ with $1 \times$ PBS and treated with Alexa Fluor ${ }^{\circledR} 488$ Goat anti-Rabbit (Invitrogen, cat\#A11008) secondary antibody (all antibodies were diluted in $1 \%$ BSA in $1 \times$ PBS). Cells were then washed $5 \times$ with $1 \times$ PBS and Anti-fade prolong gold reagent with DAPI (Invitrogen, Cat\# P36935) was added to each spot before slides were covered with coverslips, dried, and sealed. Slides were examined on a Zeiss Axio Observer Z1 inverted microscope using 10 and $20 \times$ objectives and fluorescence illumination using ExfoXcite. Images were acquired using AxioVision 4.8.2 software.

\section{PROTEIN DIGESTION}

Protein content in the non-purified ("standard") and PM-purified cytosolic and nuclear fractions collected as described above were determined using a BCA ${ }^{\mathrm{TM}}$ Protein Assay Kit (Pierce; Rockford, IL, USA) and BSA standards. After protein concentration determinations, samples were diluted with freshly made $100 \mathrm{mM}$ ammonium bicarbonate to provide concentrations of $\sim 1 \mathrm{mg} / \mathrm{ml}$ and $\mathrm{pH} \sim 8$. Three hundred microliters of each sample $(\sim 300 \mu \mathrm{g}$ of protein) were reduced, alkylated, and trypsin digested as previously described (Coombs et al., 2010). Briefly, $30 \mu$ l of freshly prepared $100 \mathrm{mM}$ dithiothreitol (DTT) in $100 \mathrm{mM}$ ammonium bicarbonate was added, incubated for $45 \mathrm{~min}$ at $60^{\circ} \mathrm{C}, 30 \mu \mathrm{l}$ of freshly prepared iodoacetic acid (500 mM solution in $100 \mathrm{mM}$ ammonium bicarbonate) was added, and the tubes were then incubated for $30 \mathrm{~min}$ at room temperature, in the dark. Finally, $50 \mu \mathrm{l}$ of $100 \mathrm{mM}$ DTT solution was added to quench the excess iodoacetic acid. Samples were digested overnight at $37^{\circ} \mathrm{C}$ with $6 \mu \mathrm{g}$ of sequencing grade trypsin (Promega, Madison, WI, USA). The samples were lyophilized and stored at $-80^{\circ} \mathrm{C}$.

\section{PEPTIDE FRACTIONATION USING 2D RP HPLC}

A newly developed orthogonal procedure (Gilar et al., 2005; Spicer et al., 2007) was employed for 2D RP (reversed-phase) high pH $\mathrm{RP}$ low $\mathrm{pH}$ peptide fractionation. Lyophilized tryptic digests were dissolved in $200 \mu \mathrm{l}$ of $20 \mathrm{mM}$ ammonium formate $\mathrm{pH} 10$ (buffer A for first dimension separation), injected onto a $1 \mathrm{~mm} \times 100 \mathrm{~mm}$ XTerra (Waters, Milford, MA, USA) column and fractionated using a $0.67 \%$ acetonitrile per minute linear gradient (Agilent 1100 Series HPLC system, Agilent Technologies, Wilmington, DE, USA) at a $150 \mu \mathrm{l} / \mathrm{min}$ flow rate. Sixty one-minute fractions were collected (covering $\sim 40 \%$ acetonitrile concentration range) and concatenated using procedures described elsewhere (Spicer et al., 2007; Dwivedi et al., 2008); the last 30 fractions were combined with the first 30 fractions in sequential order (i.e., \#1 with \#31; $\# 2$ with \#32, etc.). Combined fractions were vacuum-dried and re-dissolved in buffer A for the second dimension RP separation $(0.1 \%$ formic acid in water $)$.

A split less nano-flow Tempo LC system (Eksigent, Dublin, CA, USA) with $20 \mu \mathrm{l}$ sample injection via a $300 \mu \mathrm{m} \times 5 \mathrm{~mm}$ PepMap 100 pre-column (Dionex, Sunnyvale, CA, USA) and a $100 \mu \mathrm{m} \times 200 \mathrm{~mm}$ analytical column packed with $5 \mu \mathrm{m}$ Luna C18(2; Phenomenex, Torrance, CA, USA) were used in the second dimension separation prior to MS analysis. Both eluents A (water) and B (acetonitrile) contained $0.1 \%$ formic acid as an ionpairing modifier. A $0.33 \%$ acetonitrile per minute linear gradient $(0-30 \% \mathrm{~B})$ was used for peptide elution, providing a total $2 \mathrm{~h}$ run time per fraction in the second dimension. 


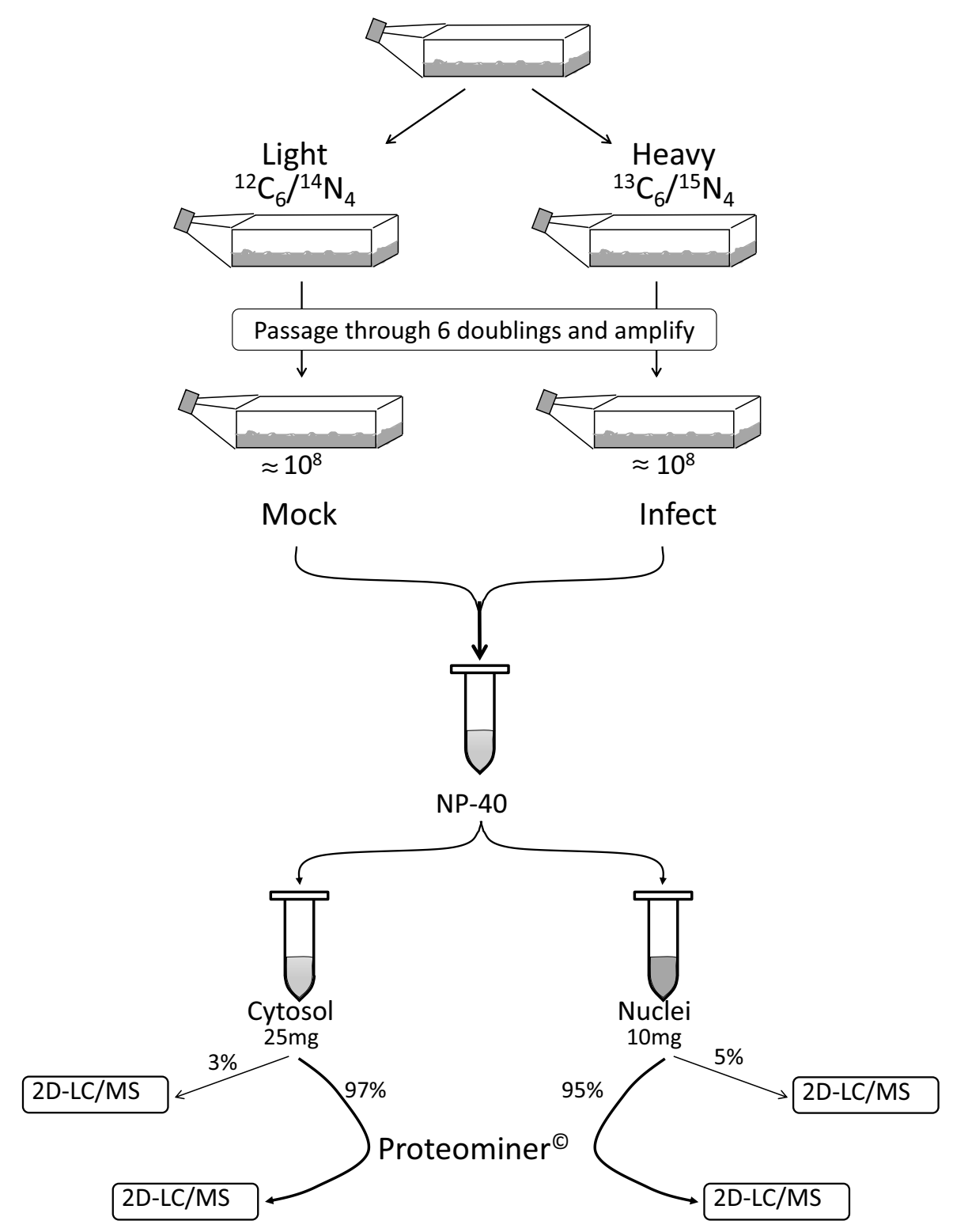

FIGURE 1 | Outline of experimental set-up. Cells were passaged through six doublings in either Light or Heavy SILAC medium and the $\mathbf{H}$ cells infected with reovirus T3D. Infected $(\mathbf{H})$ and mock-infected $(\mathbf{L})$ cells were mixed

together 1:1. After the cells were washed and lysed to separate cytosol from nucleus, 95-95\% of each fraction was non-specifically enriched for low-abundance proteins by reaction with Proteominer ${ }^{\mathrm{Tm}}(\mathrm{PM})$ beads. Each of the four fractions (two PM-enriched as well as two residual 3-5\% "standard" fractions) were then processed by 2D-HPLC/MS.

\section{MASS SPECTROMETRY, BIOINFORMATICS, AND DATA MINING}

A QStar Elite mass spectrometer (Applied Biosystems, Foster City, CA, USA) was used in a data-dependent MS/MS acquisition mode. One-second survey MS spectra were collected $(\mathrm{m} / z$ 400-1,500) followed by MS/MS measurements on the three most intense parent ions ( 80 counts/s threshold, $+2 \pm 4$ charge state, $m / z$ 100-1,500 mass range for MS/MS), using the manufacturer's "smart exit" (spectral quality five) settings. Previously targeted parent ions were excluded from repetitive MS/MS acquisition for $60 \mathrm{~s}(50 \mathrm{mDa}$ mass tolerance). Raw data files ( 30 in total for each run) were submitted for simultaneous search using standard SILAC settings for QStar instruments and were analyzed by Protein Pilot ${ }^{\circledR}$, version 4.0, using the non-redundant human gene database. A decoy database search strategy (NCBInr Homo sapiens in which all protein sequences were reversed) was used to estimate the false discovery rate, which for this dataset was $<0.8 \%$. Proteins, and their confidences and H:L ratios, were returned with GeneInfo Identifier gi accession numbers. Proteins for which at least two fully trypsin digested $\mathbf{L}$ and $\mathbf{H}$ peptides were detected at $>99 \%$ confidence were used for subsequent comparative quantitative analysis.

Differential regulation within each experimental dataset was determined by normalization of each dataset, essentially as 
described (Keshamouni et al., 2009). Briefly, every H:L ratio was converted into $\log _{2}$ space to determine geometric means and facilitate normalization. The average $\log _{2} \mathrm{H}: \mathrm{L}$ ratios and SDs of the $\log _{2}$ H:L ratios were determined for each dataset. Every proteins' $\log _{2} \mathrm{H}: \mathrm{L}$ ratio was then converted into a $z$-score, using the formula:

$$
\mathrm{Z}-\operatorname{score}(\sigma) \text { of }[b]=\frac{\begin{array}{c}
\log _{2} \mathrm{H}: \mathrm{L}[b]-\text { average of } \\
\left(\log _{2} \text { of each member, } a \ldots n\right)
\end{array}}{\left(\begin{array}{c}
\text { standard deviation of } \\
\left(\log _{2} \text { of each member, } a \ldots n\right)
\end{array}\right.}
$$

where " $b$ " represents an individual protein in a dataset population $a . . n$, and $z$-score is the measure of how many SD units (expressed as “ $\sigma$ ") that protein's $\log _{2} \mathbf{H}: \mathbf{L}$ ratio is away from its population mean. Thus, a protein with a $z$-score $>1.645 \sigma$ indicates that protein's differential expression lies outside the $90 \%$ confidence level, $>1.960 \sigma$ indicates outside the $95 \%$ confidence level, $2.576 \sigma$ indicates $99 \%$ confidence, and $3.291 \sigma$ indicates $99.9 \%$ confidence. $z$-Scores $>1.960$ were considered significant. gi numbers of all significantly regulated proteins were converted into HGNC identifiers by Uniprot ${ }^{1}$ and HGNC terms were submitted to and analyzed by the DAVID bioinformatic suite at the NIAID, version 6.7 (Dennis et al., 2003; Huang et al., 2009a) and gene ontologies examined with the "FAT" datasets. The gi numbers were also submitted to, and pathways constructed with, Ingenuity Pathway Analysis software $\left(\mathrm{IPA}^{\circledR}\right)$.

\section{RESULTS AND DISCUSSION \\ IDENTIFICATION OF ALTERED HOST PROTEINS}

We combined $\sim 10^{8} \mathbf{H}$-labeled reovirus-infected HeLa cells with an equivalent amount of $\mathbf{L}$-labeled non-infected cells, lysed the cells to generate cytosolic and nuclear fractions, and reacted $\sim 95 \%$ of each fraction with a commercially available random hexapeptide library $\left(\mathrm{PM}^{\mathrm{TM}}\right)$ to enrich for low-abundance proteins. This strategy was chosen to attempt to complement the proteomic coverage of high-abundance and medium-abundance proteins expected from standard 2D-HPLC/MS processing (outlined in Figure 1). We also confirmed that the majority of HeLa cells demonstrated virus replication under our experimental conditions by 12-24hpi, as measured by immunofluorescent microscopy (Figure 2). Our standard 2D-HPLC/MS process identified 2,472 proteins from 21,989 non-redundant H:L peptide pairs in the cytosolic fraction. However, exclusion of those proteins whose identification confidence was $<99 \%$ reduced the number of identified proteins to 1,903 (Table 1; Figure 3A). Using similar criteria, we found 1,657 proteins at $\geq 99 \%$ confidence in the cytosolic fraction reacted with the PM library and about 1,100 proteins in each of the nuclear fractions. Since crude nuclear fractions were frozen and no attempts were made to remove traces of cytosolic proteins from this fraction, these assays were meant to provide additional cell fractions rather than to allow meaningful distributional characterization and the "nuclear" fractions were expected to be contaminated with some cytosolic proteins.

${ }^{1}$ http://www.uniprot.org/

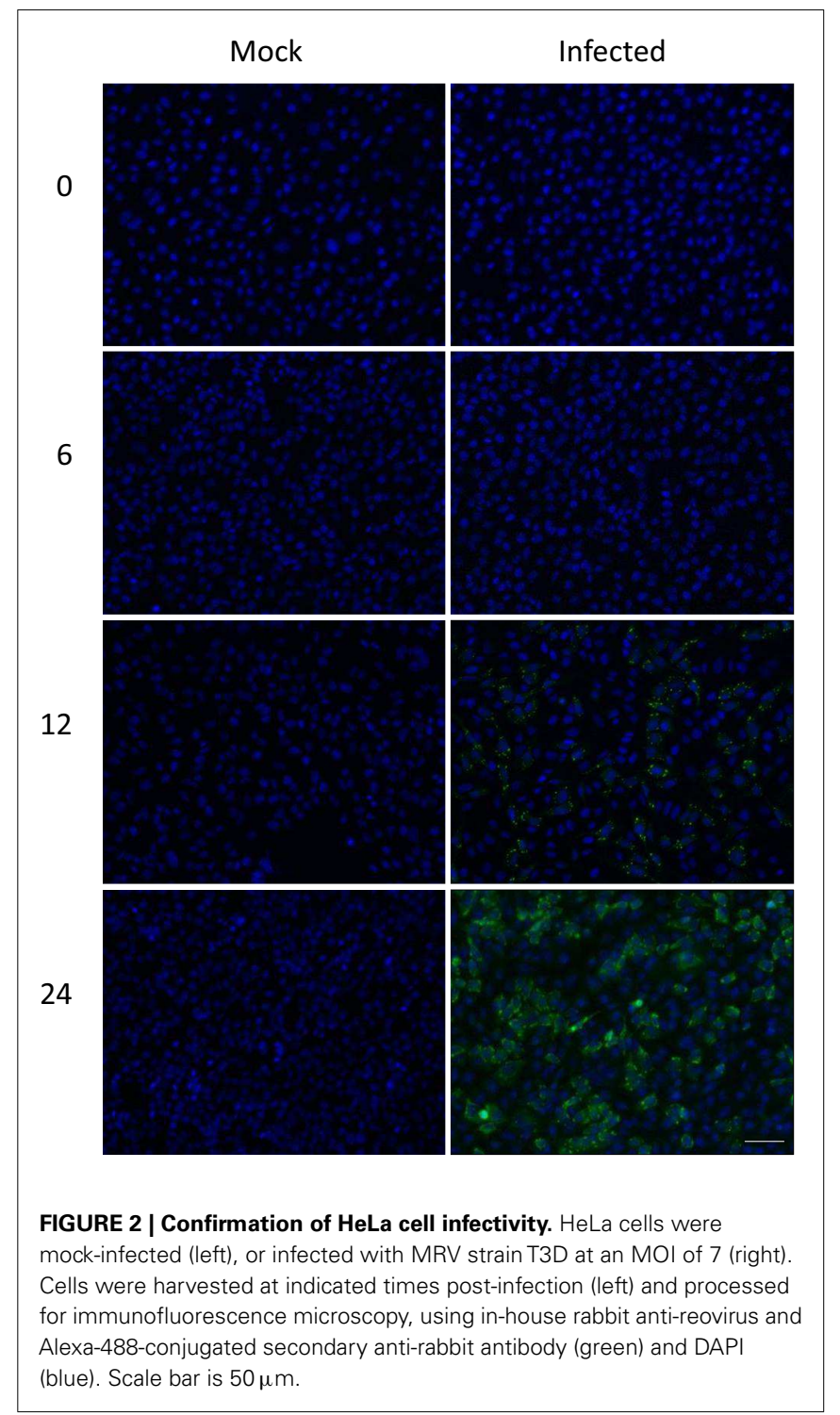

Combination of all fractions, and removal of all proteins identified by only a single peptide, resulted in identification and measurement of 2,759 total unique protein pairs. Each protein's H:L ratio was converted to log space and inspection of each dataset indicated variability in each dataset's mean $\log _{2}$ value and in each dataset's $\log _{2}$ SD (Figure 3B; Table 1). Thus, every proteins' $\mathbf{H}: \mathbf{L}$ ratio was converted into a $z$-score as described in Section "Materials and Methods" (and in Coombs et al., 2010) to facilitate comparisons of each dataset. A number of proteins with significantly high or low $\log _{2}$ values and corresponding $z$-scores represented keratins and other proteins identified in other studies as probable contaminants (i.e., S200 binding proteins); thus, these proteins were removed from further calculations.

Stratification of each protein's $\mathbf{H}: \mathbf{L}$ ratio and its corresponding $z$-score indicated that numerous proteins in each sample could be considered significantly regulated. For example, of the 1,838 proteins identified in the standard cytosolic preparation, 40 were up-regulated at $95 \%$ confidence and 14 were also up-regulated 
Table 1 | Number of peptides, proteins, $\log _{2} \mathrm{H}: \mathrm{L}$ ratio means and SD, and z-scores of SILAC-measured HeLa cell proteins.

\begin{tabular}{|c|c|c|c|c|}
\hline & \multicolumn{2}{|c|}{ Cytosol } & \multicolumn{2}{|c|}{ Nuclei } \\
\hline & Standard $^{1}$ & Proteominer $^{2}$ & Standard & Proteominer \\
\hline Total number of peptide pairs ${ }^{3}$ & 24,927 & 17,484 & 14,594 & 13,108 \\
\hline Total number of proteins 4 & 1,903 & 1,657 & 1,104 & 1,135 \\
\hline Number of proteins analyzed 5 & 1,838 & 1,570 & 1,047 & 1,064 \\
\hline Mean $\log _{2} \mathrm{H}: \mathrm{L}$ ratios & 0.0124 & 0.0009 & 0.0055 & 0.0156 \\
\hline SD of $\log _{2} \mathrm{H}: \mathrm{L}$ ratios & 0.2759 & 0.3526 & 0.3035 & 0.3314 \\
\hline Number of proteins at $z$-score cutoff of: $\pm 1.960 \sigma(95 \%)$ & $40,33^{6}$ & 34,27 & 32,29 & 18,20 \\
\hline $\pm 2.576 \sigma(99 \%)$ & 21,17 & 19,20 & 14,15 & 14,15 \\
\hline $\pm 3.291 \sigma(99.9 \%)$ & 14,5 & 8,17 & 11,7 & 8,11 \\
\hline
\end{tabular}

${ }^{1}$ Indicated cellular fraction was trypsinized and directly processed by two-dimensional HPLC/MS.

${ }^{2}$ Indicated cellular fraction was incubated with Proteominer ${ }^{\mathrm{T}}$ beads, eluted, trypsinized, and processed by 2-D HPLC/MS.

${ }^{3}$ Total number of $\boldsymbol{H}: \mathbf{L}$ peptide pairs for all proteins identified at confidence level $\geq 99 \%$.

${ }^{4}$ Total number of proteins identified at confidence level $\geq 99 \%$.

${ }^{5}$ Number of proteins analyzed after those identified by only a single peptide, as well as possible contaminants, removed.

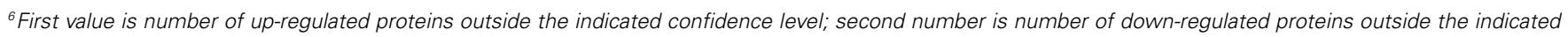
confidence level.

at $99.9 \%$ confidence (Table $\mathbf{1}$ ). Thirty three proteins in the same dataset were down-regulated at $95 \%$ confidence, and five of these proteins were also down-regulated at $99.9 \%$ confidence. Inspection of protein $\mathrm{H}: \mathrm{L}$ ratios and $z$-scores indicated that most proteins differentially regulated at $>95 \%$ confidence had $\mathrm{H}$ :L ratios altered by $>1.5$-fold. Thus, proteins observed more than a single time were considered significantly regulated if at least one of their observations had a $z$-score $\geq 1.960 \sigma$, if another observation in the same type of fraction (i.e., standard cytosolic and PM cytosolic) was no more than $0.75 \sigma$ in the opposite direction, and if the average $\mathbf{H}: \mathbf{L}$ ratio was $>1.5$-fold. Using the above criteria, we identified and measured 66 proteins that were significantly upregulated and 67 proteins that were significantly down-regulated (Table 2).

Several of the up-regulated and non-regulated proteins that were identified and measured in the SILAC analysis were confirmed by Western blotting (Figure 4). Most Western blot results confirmed the SILAC-determined results although some differences in measured ratios probably reflect different levels of sensitivity of the two assays.

\section{PROTEINS UP-REGULATED BY REOVIRUS INFECTION ARE ASSOCIATED WITH ANTIMICROBIAL AND ANTIVIRAL RESPONSES, GTPASE ACTIVITY, NUCLEOTIDE BINDING, INTERFERON SIGNALING, AND ENZYMES ASSOCIATED WITH ENERGY GENERATION}

Proteins, and their levels of regulation, were analyzed by a variety of means. Protein gi numbers were imported into Uniprot (see text foot note 1) and converted into HUGO nomenclature committee (HGNC) identifiers. The HGNC IDs that represented significantly up-regulated and down-regulated proteins at the 95\% confidence interval were then imported into DAVID (Dennis et al., 2003; Huang et al., 2009b), gene identifications converted to Entrez gene IDs by that suite of programs, and gene ontological biological processes and molecular functions identified at 95\% confidence (Figure 5).
Up-regulated proteins were assigned to 18 GOTERM biological processes at 95\% confidence (Figure 5, upper), that included cellular respiration, energy metabolism, and responses to viruses. Up-regulated proteins were also assigned to 11 functional groups (Figure 5) including primarily nucleotide binding. Protein gi numbers and levels of regulation were also imported into the Ingenuity Pathways Analysis (IPA ${ }^{\circledR}$ ) tool which identified 13 GO categories (Figure 6A). Up-regulated proteins were enriched in growth factor, ion channel, kinase, phosphatase, and transmembrane receptor categories, whereas there were proportionally fewer up-regulated peptidase, translation regulators, and "other" (unknown) categories. Interacting pathways were also constructed by IPA. A total of 22 pathways were identified at a confidence level of $95 \%$ or greater. Five of these pathways, each with 11 or more "focus" members (significantly up- or down-regulated proteins), shared common members, and it was possible to build a single, merged pathway (Figure 6B). One other pathway (RNA posttranscriptional modification) contained only five focus molecules. The other 16 pathways consisted of several proteins, but contained only a single focus protein (data not shown). The five networks that contained 11 or more focus members corresponded to antimicrobial and inflammatory response; gastrointestinal disease; cell cycle, death, growth, proliferation, and movement; and DNA replication pathways (Figure 6C). Proteins present in the pathways and identified in our analyses as up-regulated are depicted in shades of red and include FADS3, IFIT1, and SAP130. Proteins present in the pathways and identified as down-regulated are shown in green and include AZGP1, LTF, and WDR5. Proteins present in the pathways and identified in our analyses, but neither up- nor down-regulated, are depicted in gray and include NF-KB complex, MAPK1, and TUBB, and proteins known to participate in the pathways but not identified in our analyses are shown in white and include AGER, IL28A, and MARK1-3. IPA analyses identify interaction nodes. For example, several of the highly up-regulated proteins interact with few other proteins, 
A

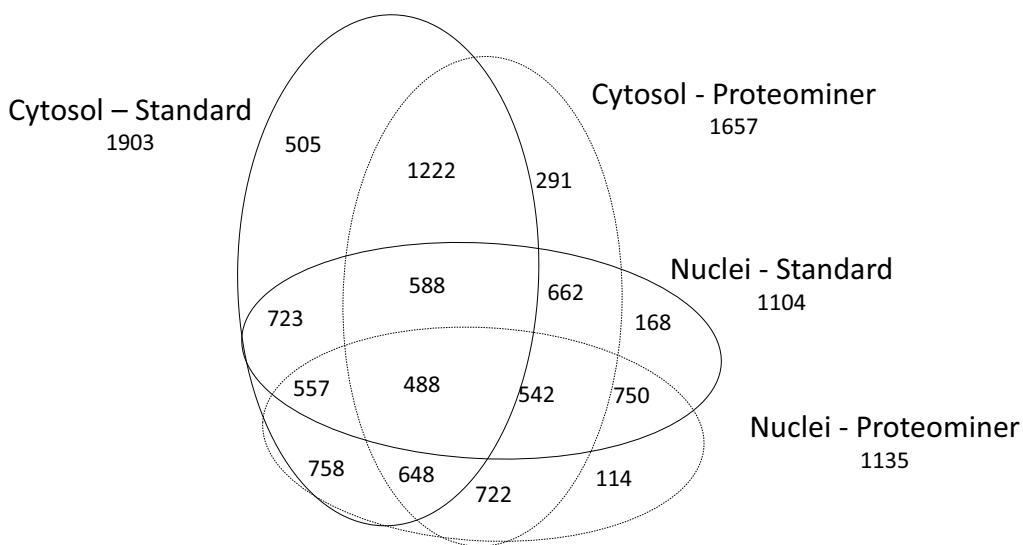

B

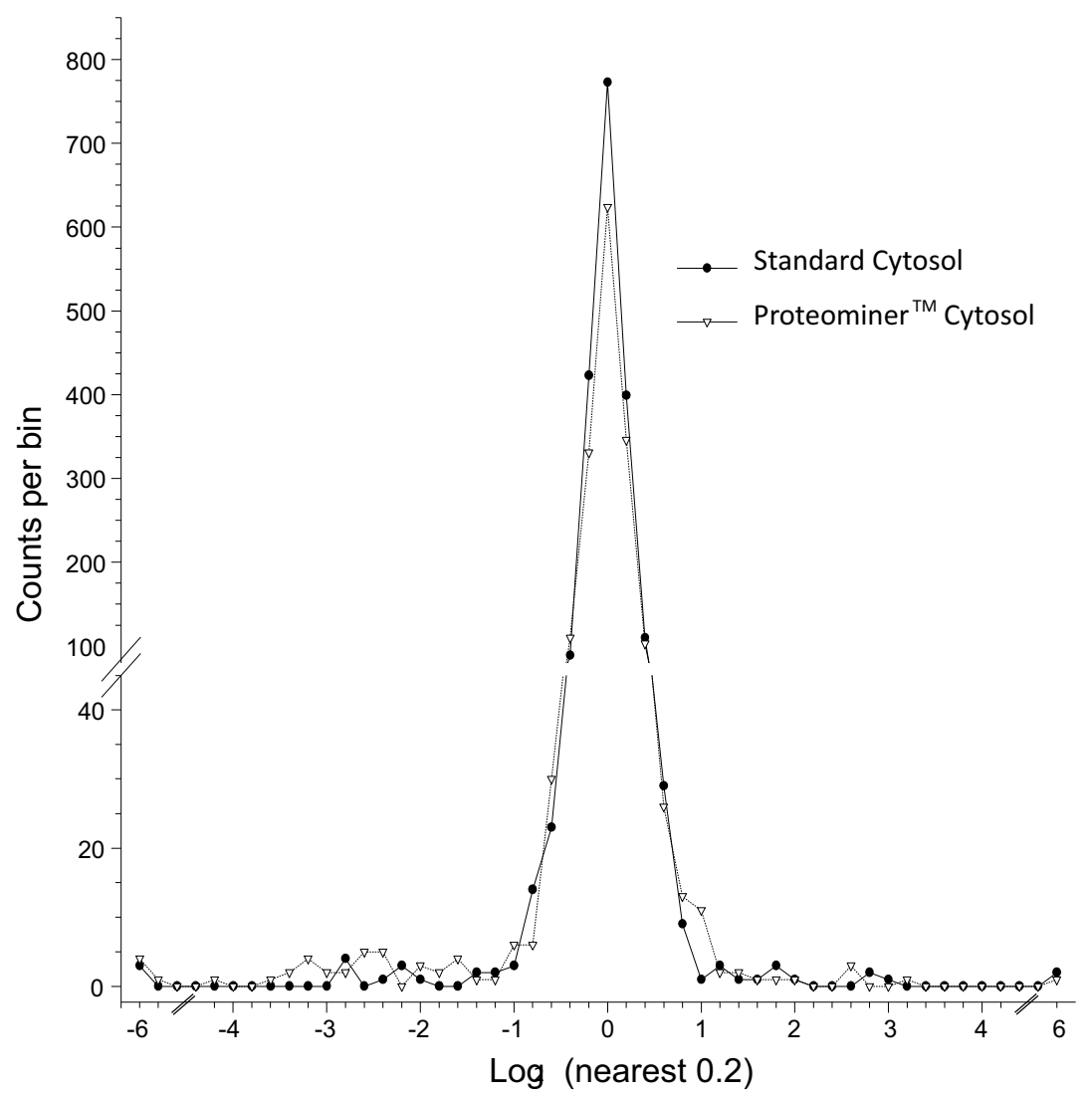

FIGURE 3 | Distributions of proteins identified in various experiments. (A) Venn diagram of numbers of identified proteins from various analyses. (B) Frequency distributions of identified proteins in two virus-infected sample sets, with $\mathbf{H}: \mathbf{L}$ ratios expressed as $\log _{2}$ values. Positive values represent

but some, such as STAT, ISG15, and Mx1 interact with four or more. Many of these molecules are involved in innate immunity. In addition, the interferon-induced, large GTPase dynamin-like Mx proteins are important anti viral proteins, particularly against RNA viruses (Haller and Kochs, 2002; Haller et al., 2009) and have been identified in several proteomic studies as up-regulated up-regulated host proteins in virus-infected cells; negative values represent down-regulated host proteins. Characteristics of all peptide and protein distributions, mean $\log _{2} \mathbf{H}: \mathbf{L}$ ratios, and SDs of $\log _{2} \mathbf{H}: \mathbf{L}$ ratios are shown in Table 1.

by influenza virus infection (Baas et al., 2006; Vester et al., 2009; Coombs, 2011). In addition, modulation of interferon response by reoviruses, including through STAT activation, has been demonstrated (Goody et al., 2007; Sherry, 2009; Zurney et al., 2009). Thus, our SILAC observations are validated by, and support, previous findings. Similarly, a few of the down-regulated proteins 
Table 2 | Significantly affected HeLa cell proteins after reovirus infection.

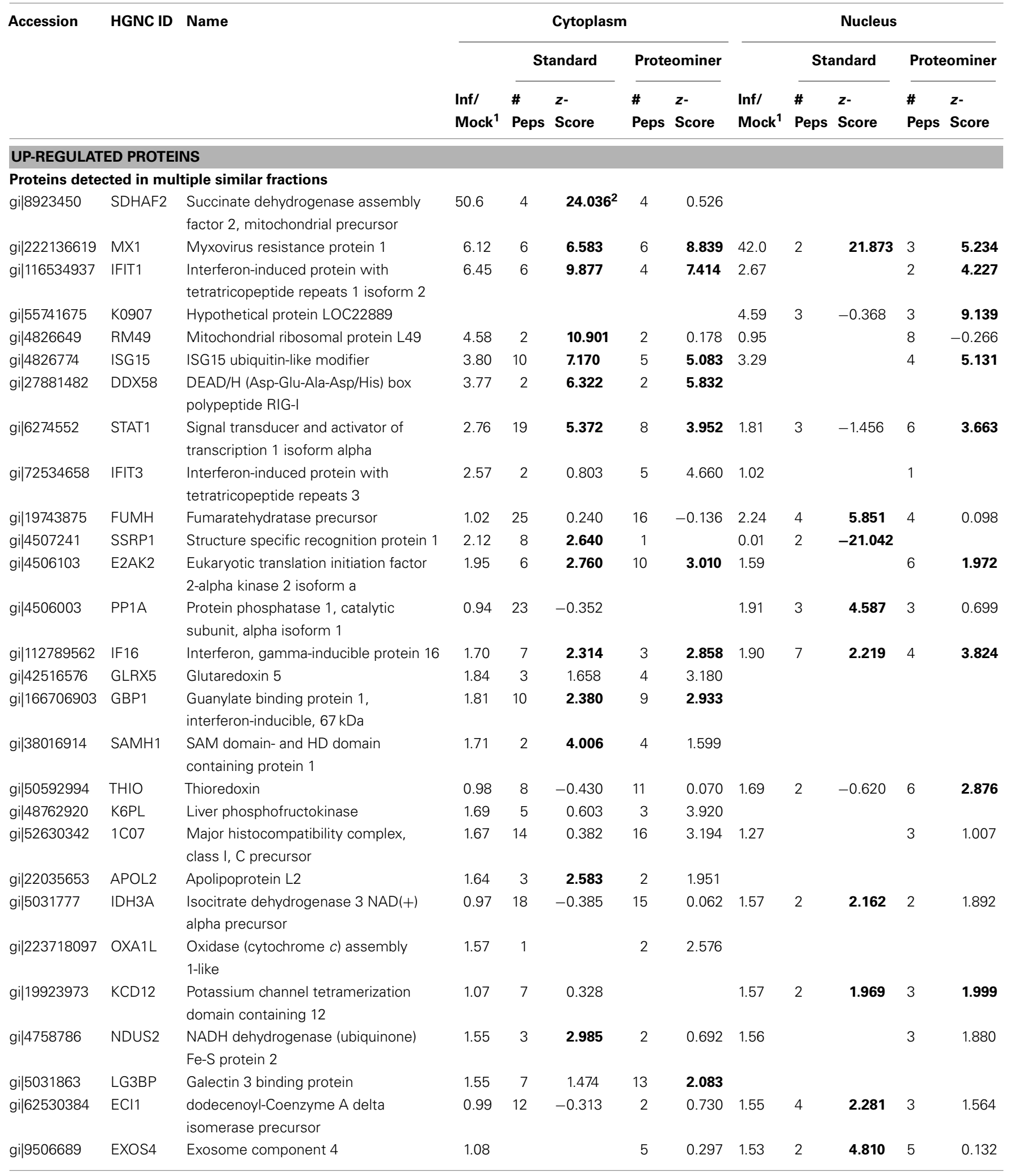


Table 2 | Continued

\begin{tabular}{|c|c|c|c|c|c|c|c|c|c|c|c|c|}
\hline \multirow[t]{2}{*}{ Accession } & \multirow[t]{2}{*}{ HGNC ID } & \multirow[t]{2}{*}{ Name } & \multicolumn{5}{|c|}{ Cytoplasm } & \multicolumn{5}{|c|}{ Nucleus } \\
\hline & & & $\begin{array}{l}\text { Inf/ } \\
\text { Mock }\end{array}$ & \multicolumn{2}{|c|}{ Standard } & \multicolumn{2}{|c|}{ Proteominer } & $\begin{array}{l}\text { Inf/ } \\
\text { Mock }\end{array}$ & \multicolumn{2}{|c|}{ Standard } & \multicolumn{2}{|c|}{ Proteominer } \\
\hline \multicolumn{13}{|c|}{ Proteins detected multiple times/regulated at least once } \\
\hline gi|5453740 & ML12A & $\begin{array}{l}\text { Myosin, light chain 12A, regulatory, } \\
\text { non-sarcomeric }\end{array}$ & 6.89 & 13 & 10.050 & & & 0.84 & & & 10 & -0.811 \\
\hline gi|24307901 & $\mathrm{IFI} 35$ & Interferon-induced protein 35 & 3.71 & 2 & 6.811 & & & 3.04 & 3 & 5.269 & & \\
\hline gi|5174513 & SMAD3 & $\begin{array}{l}\text { mothers against decapentaplegic } \\
\text { homolog } 3 \text { isoform } 1\end{array}$ & 1.23 & & & 1 & & 2.03 & & & 3 & 3.044 \\
\hline gi|33469966 & SCFD1 & $\begin{array}{l}\text { Vesicle transport-related protein } \\
\text { isoform a }\end{array}$ & 0.98 & 3 & 1.814 & 8 & -0.875 & 1.68 & 4 & 2.439 & & \\
\hline gi|5902076 & SRSF1 & $\begin{array}{l}\text { Splicing factor, arginine/serine-rich } 1 \\
\text { isoform } 1\end{array}$ & 1.63 & & & 2 & 1.994 & 1.07 & 14 & 0.109 & 25 & 0.336 \\
\hline gi|39780588 & TSR1 & TSR1, 20S rRNA accumulation & 1.00 & 1 & & & & 1.58 & 4 & 2.147 & & \\
\hline gi|13540606 & CLPB & Caseinolytic peptidase B & 1.52 & 2 & 2.158 & & & 0.49 & 1 & & & \\
\hline \multicolumn{13}{|c|}{ Proteins detected once } \\
\hline gi|17921993 & TВA3C & Tubulin, alpha 3c & 100 & 86 & 24.036 & & & & & & & \\
\hline gi|31543983 & ARFG2 & $\begin{array}{l}\text { ADP-ribosylation factor GTPase } \\
\text { activating protein } 2\end{array}$ & & & & & & 5.73 & 3 & 8.278 & & \\
\hline gi|20631967 & BAX & Apoptosis regulator BAX isoform sigma & 1.87 & & & 2 & 2.559 & & & & & \\
\hline gi|4757876 & BST2 & Bone marrow stromal cell antigen 2 & & & & & & 1.87 & & & 4 & 2.666 \\
\hline gi|222144328 & MYL12B 3 & $\begin{array}{l}\text { Myosin regulatory light chain MRCL2 } \\
\text { isoform B }\end{array}$ & & & & & & 1.83 & 6 & 2.847 & & \\
\hline gi|53828918 & PGTA & Rabgeranylgeranyltransferase alpha & 1.83 & & & 2 & 2.459 & & & & & \\
\hline gi|190014625 & RRP44 & DIS3 mitotic control isoform b & & & & & & 1.81 & 2 & 2.810 & & \\
\hline gi|5729820 & SYFM & $\begin{array}{l}\text { Phenylalanyl-tRNAsynthetase } 2 \\
\text { precursor }\end{array}$ & 1.79 & & & 2 & 2.382 & & & & & \\
\hline gi|4505467 & NT5E & $\begin{array}{l}5^{\prime} \text { Nucleotidase isoform } 1 \\
\text { preproprotein }\end{array}$ & & & & & & 1.74 & 2 & 2.618 & & \\
\hline gi|4505895 & PLRG1 & $\begin{array}{l}\text { Pleiotropic regulator } 1 \text { (PRL1 homolog, } \\
\text { Arabidopsis) }\end{array}$ & & & & & & 1.71 & 2 & 2.540 & & \\
\hline gi|4505587 & PA1B3 & $\begin{array}{l}\text { Platelet-activating factor } \\
\text { acetylhydrolase, isoform lb, gamma } \\
\text { subunit }\end{array}$ & 1.67 & 2 & 2.634 & & & & & & & \\
\hline gi|28395033 & $\mathrm{RHOC}$ & $\begin{array}{l}\text { Ras homolog gene family, member } \mathrm{C} \\
\text { precursor }\end{array}$ & 1.62 & & & 18 & 1.981 & & & & & \\
\hline gi|148536825 & CO4A1 & Alpha 1 type IV collagen preproprotein & 1.59 & 2 & 2.380 & & & & & & & \\
\hline
\end{tabular}


Table 2 | Continued

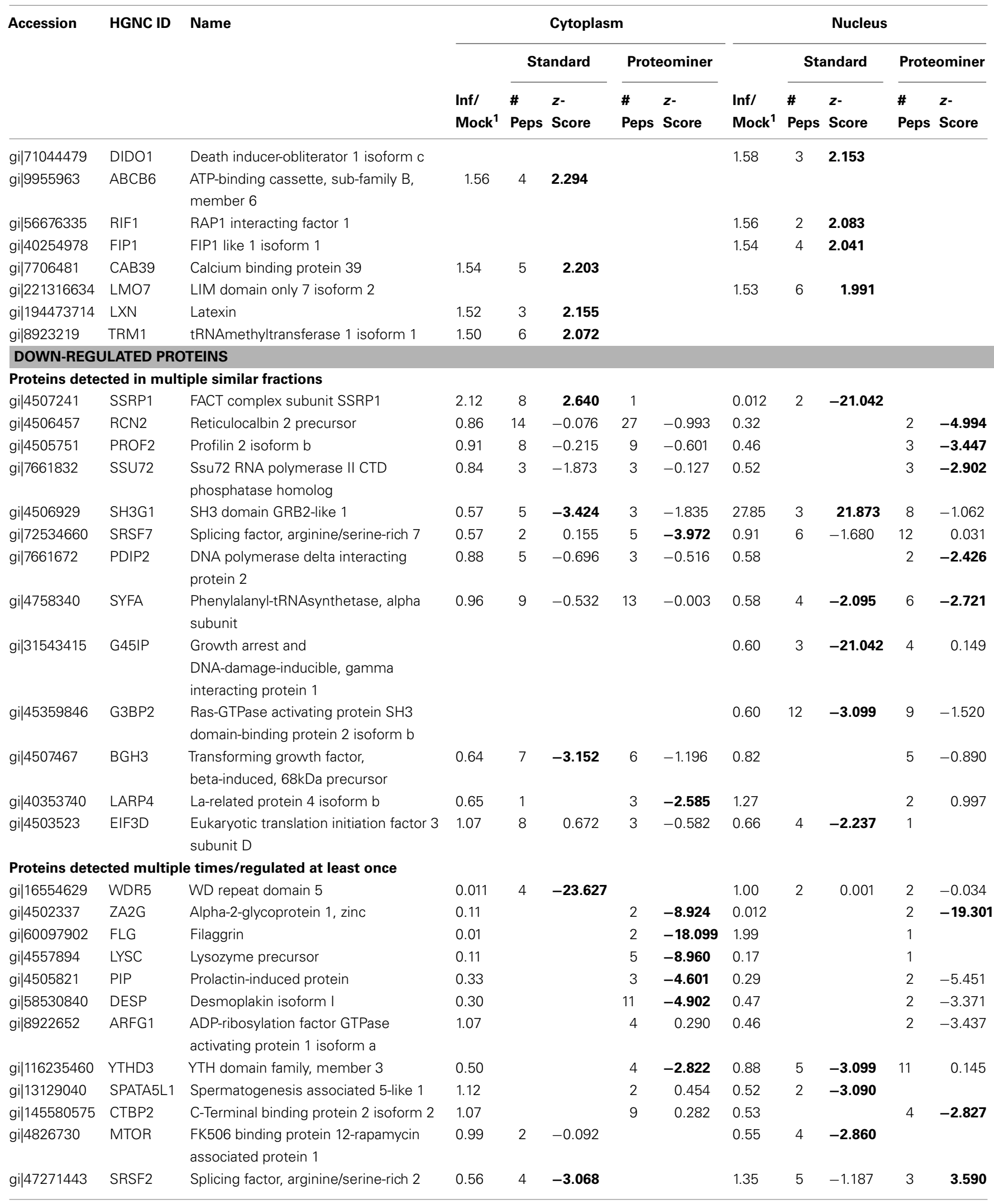


Table 2 | Continued

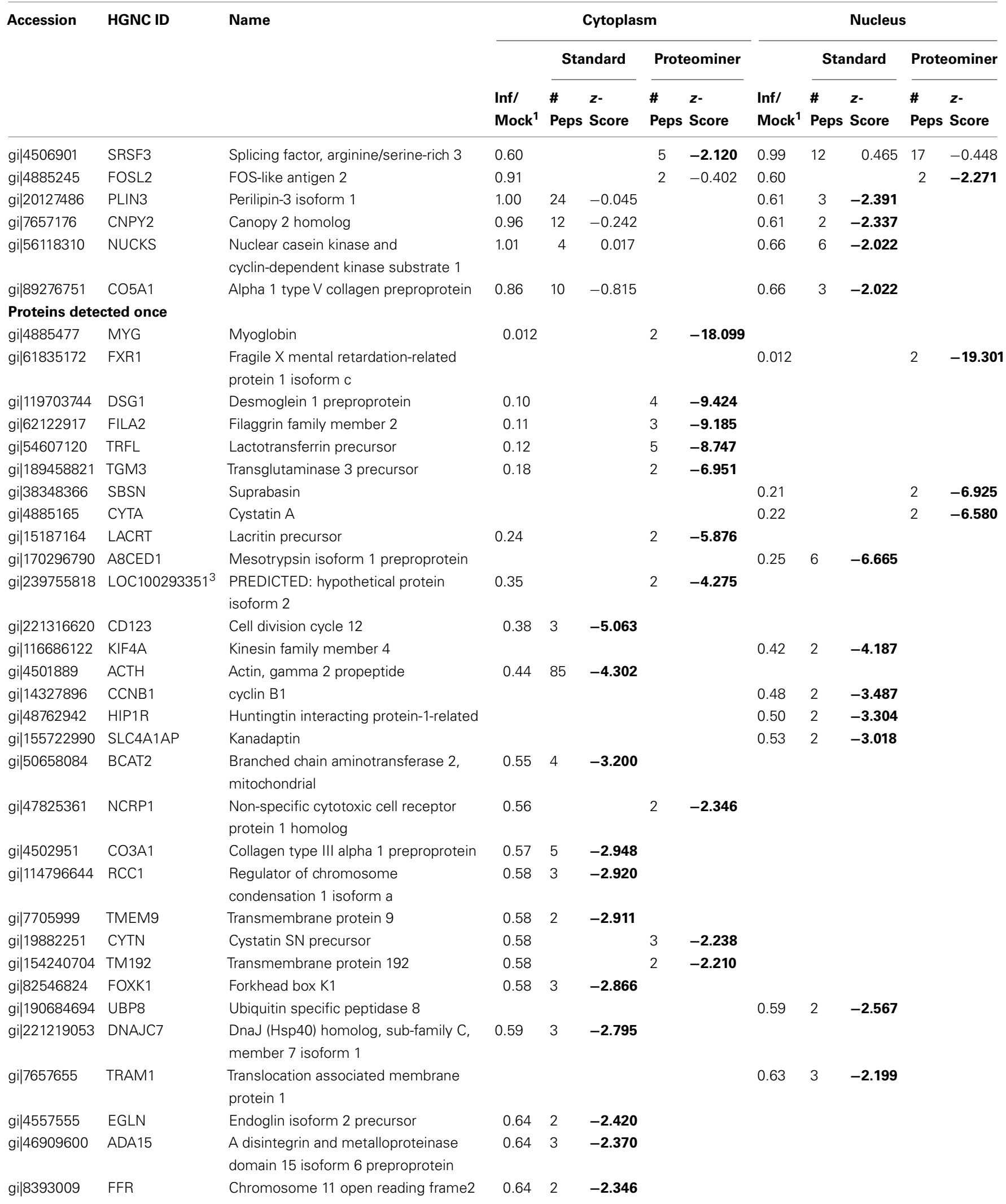


Table 2 | Continued

\begin{tabular}{|c|c|c|c|c|c|c|c|c|c|c|c|c|}
\hline \multirow[t]{3}{*}{ Accession } & \multirow[t]{3}{*}{ HGNC ID } & \multirow[t]{3}{*}{ Name } & \multicolumn{5}{|c|}{ Cytoplasm } & \multicolumn{5}{|c|}{ Nucleus } \\
\hline & & & \multirow[b]{2}{*}{$\begin{array}{l}\text { Inf/ } \\
\text { Mock } 1\end{array}$} & \multicolumn{2}{|c|}{ Standard } & \multicolumn{2}{|c|}{ Proteominer } & \multirow[b]{2}{*}{$\begin{array}{l}\text { Inf/ } \\
\text { Mock } 1\end{array}$} & \multicolumn{2}{|c|}{ Standard } & \multicolumn{2}{|c|}{ Proteominer } \\
\hline & & & & $\begin{array}{l}\# \\
\text { Peps }\end{array}$ & $\begin{array}{l}z- \\
\text { Score }\end{array}$ & $\begin{array}{l}\# \\
\text { Peps }\end{array}$ & $\begin{array}{l}z- \\
\text { Score }\end{array}$ & & $\begin{array}{l}\# \\
\text { Peps }\end{array}$ & $\begin{array}{l}z- \\
\text { Score }\end{array}$ & $\begin{array}{l}\# \\
\text { Peps }\end{array}$ & $\begin{array}{l}z- \\
\text { Score }\end{array}$ \\
\hline gi|109255232 & CE170 & $\begin{array}{l}\text { Centrosomal protein } 170 \mathrm{kDa} \text { isoform } \\
\text { gamma }\end{array}$ & 0.65 & 2 & -2.330 & & & & & & & \\
\hline gi|63176611 & SLTM & $\begin{array}{l}\text { SAFB-like transcription modulator } \\
\text { isoform a }\end{array}$ & & & & & & 0.65 & 5 & -2.051 & & \\
\hline gi|5453958 & PPP5 & $\begin{array}{l}\text { Protein phosphatase } 5 \text {, catalytic } \\
\text { subunit }\end{array}$ & 0.66 & 3 & -2.249 & & & & & & & \\
\hline gi|8922331 & MGN2 & Mago-nashi homolog B & & & & & & 0.66 & 4 & -1.986 & & \\
\hline gi|30061491 & E41L1 & $\begin{array}{l}\text { Erythrocyte membrane protein band } \\
4.1 \text {-like } 1 \text { isoform b }\end{array}$ & 0.665 & 5 & -2.178 & & & & & & & \\
\hline
\end{tabular}

${ }^{1}$ Weighted $\boldsymbol{H}: \mathbf{L}$ ratios, scaled to number of measured peptides in each sample, if detected in both Standard and Proteominer samples.

${ }^{2}$ Bolding indicates a significant z-score (95\% confidence), either $>1.960$ or $<-1.960$.

${ }^{3}$ Gene removed from $N C B I$ database.

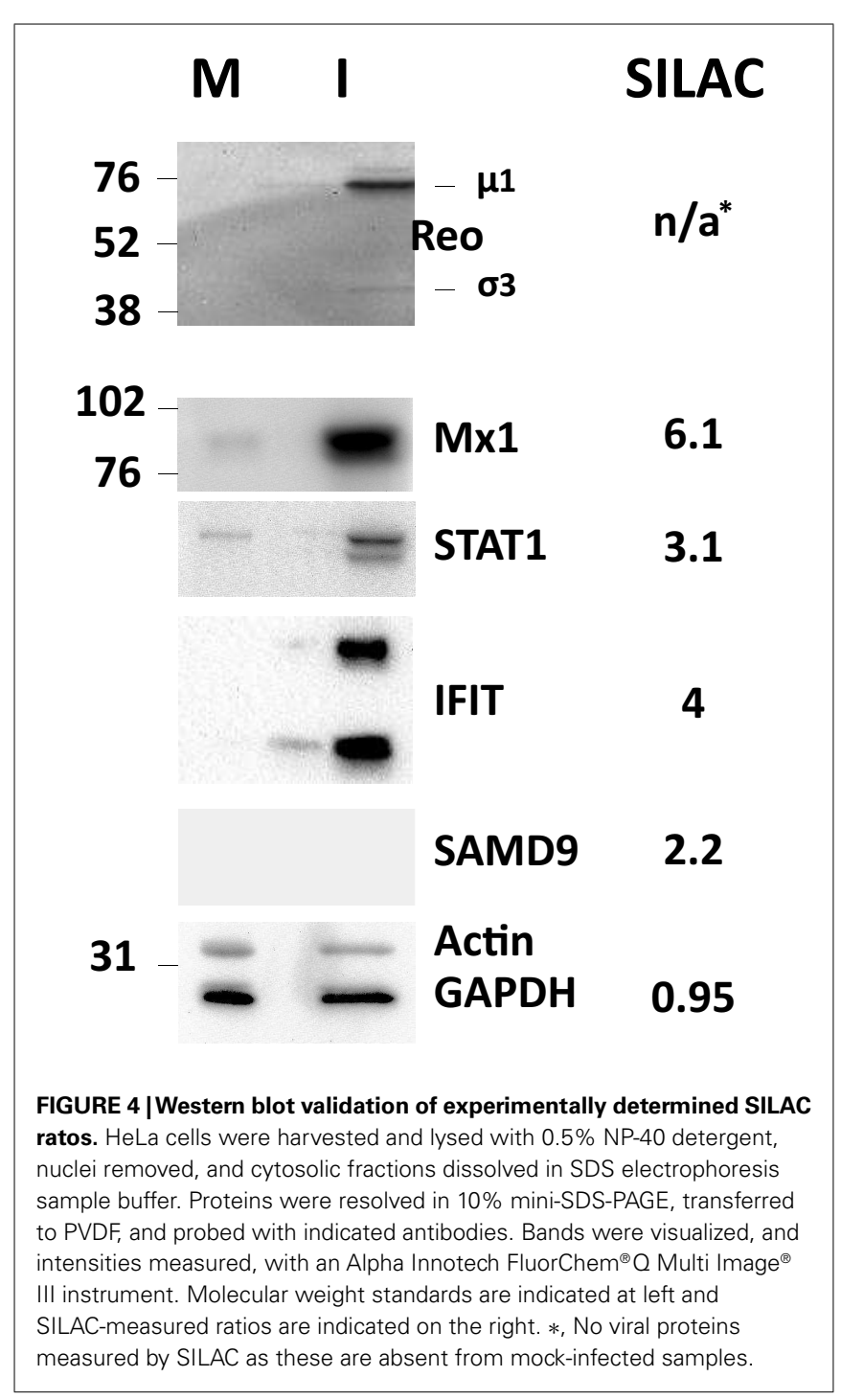

interact with few partners, but several, including WDR5, appear as interaction "hubs." We identified numerous other interaction hubs, such as LGAL53 and NF-KB which were not, themselves, significantly altered, but which interacted with several differentially regulated proteins.

\section{PROTEINS DOWN-REGULATED BY REOVIRUS INFECTION ARE ASSOCIATED WITH CELL DIFFERENTIATION, DERMAL DIFFERENTIATION, AND MOLECULAR BINDING}

Down-regulated proteins were assigned to 33 biological processes at 95\% confidence (Figure 5, lower), that included cell differentiation, peptide cross-linking, and ectoderm and endoderm development. Down-regulated proteins were also assigned to seven functional groups, including structural molecule activity and various factor binding roles (Figure 5). IPA-generated GO categories indicated down-regulated proteins were enriched in unknown categories whereas there were proportionally fewer down-regulated enzymatic and transporter categories (Figure 6A). Additional IPA pathway analyses indicated numerous components of the "Interferon signaling" and "Role of PKR in interferon induction and antiviral response" canonical pathways were significantly up-regulated, whereas numerous arms of the "Regulation of actinbased motility by rho" canonical pathway were down-regulated (data not shown).

\section{PROTEOMINER ENRICHMENT LED TO IDENTIFICATION OF COMPARABLE NUMBERS OF PROTEINS, BUT PM-ENRICHED PROTEINS WERE IDENTIFIED BY FEWER PEPTIDES}

As indicated earlier, 1,903 proteins were identified in the standard cytosolic fraction, compiled from 24,927 H:L peptide pairs (Table 1). This corresponds to an average of 13.1 peptides/protein $(S D \pm 20.5$; Figure 7). In contrast, PM enrichment of the cytosolic fraction led to identification of 17,484 H:L peptide pairs and 1,657 proteins (average $=10.3$ peptides, \pm 15.8 ). Slightly more proteins were identified in the PM-enriched nuclear fraction than in the standard nuclear fraction, but the average numbers of 


\section{Up-regulated}

Biological Processes

Generation of precursor metat Energy derivation by oxidation of organic compounds Cellular respiratio ncRNA processing

RNA processing Aerobic respiration Cellular macromolecular complex assembly
Electron transport chain Cellular macromolecular complex subunit organization Ribonucleoprotein complex biogenesis Macromolecular complex assembly Immune response ncRNA metabolic process Macromolecular complex subunit organizationAcetyl-CoA catabolic process

Tricarboxylic acid cycle

Ribosome biogenesis

\section{Molecular Functions \\ Down-regulated \\ Biological Processes}

\section{$-\log (p-v a l u e)$}
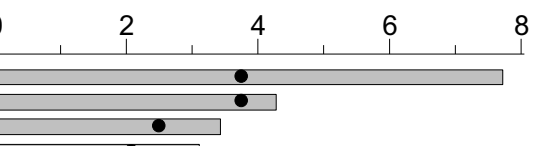
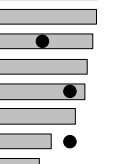

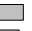

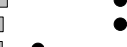

2

0
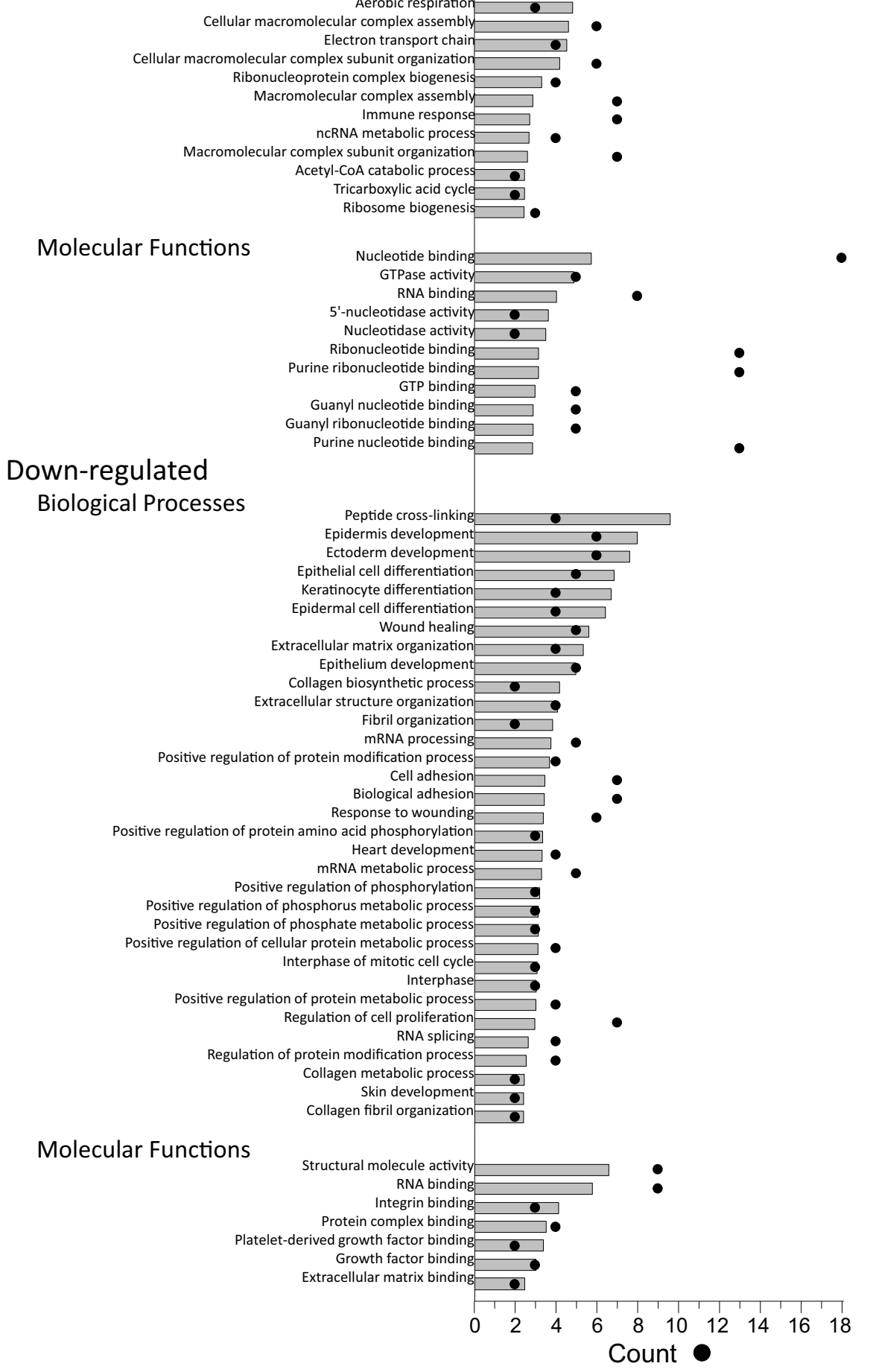

FIGURE 5 | Gene ontology analyses of up-regulated and down-regulated proteins. The proteins identified in Table $\mathbf{2}$ were imported into the DAVID gene ontology suite of programs at the NIAID, gene identifications converted by that program, and ontological functions determined by GOTERM. 
A

\section{Total}

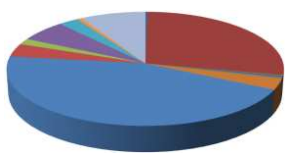

Up

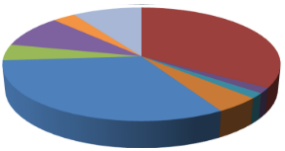

Down

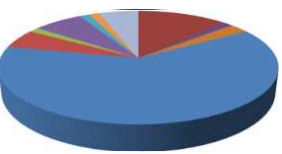

Cytokine

Enzyme

G-protein coupled receptor Growth factor

lon channel

Kinase

Other

Peptidase

Phosphatase

Transcription Regulator

Translation Regulator

Transmembrane receptor

Transporter
C

Antimicrobial Response, Inflammatory Response, Dermatological Diseases and Conditions

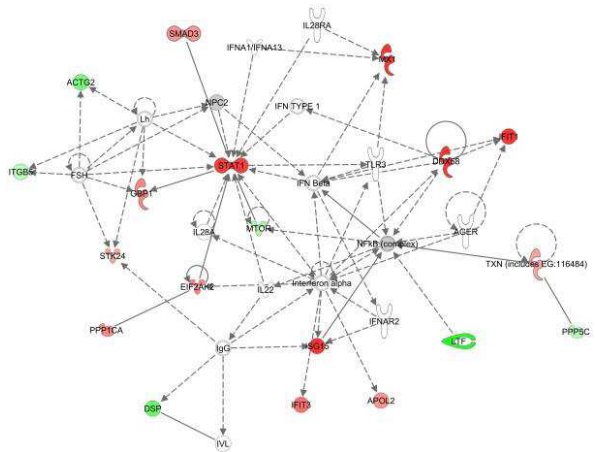

B

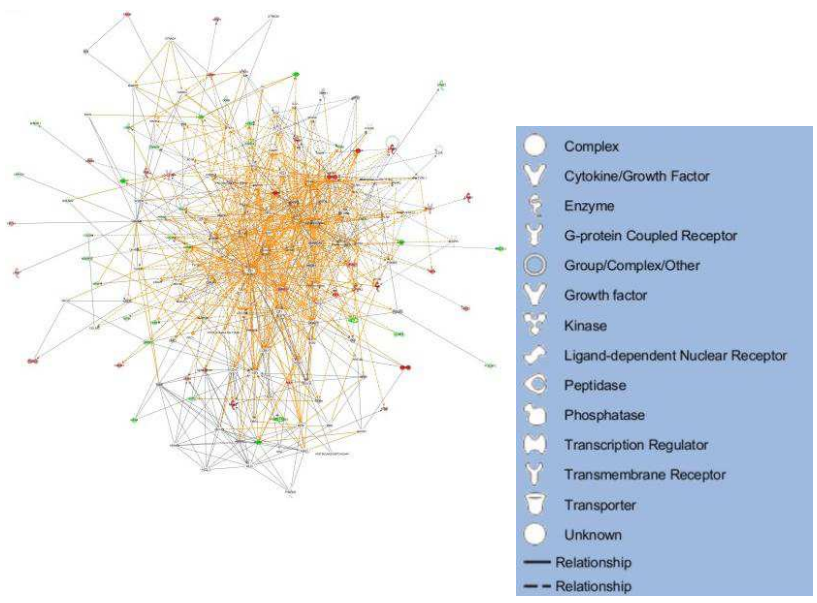

Gastrointestinal Disease, Hepatic System Disease,

Organismal Injury and Abnormalities

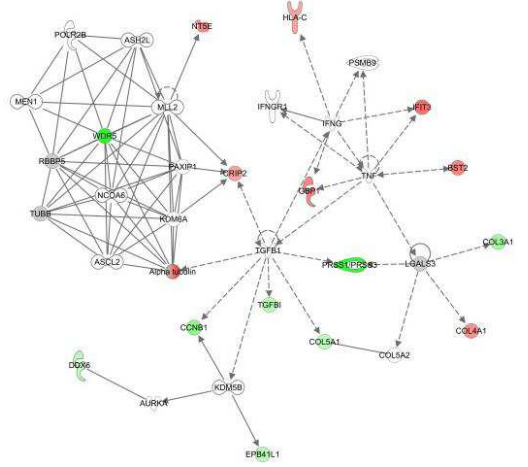

Cell Cycle, Gene Expression, DNA Replication, Recombination and Repair Cell Cycle, Cellular Growth and Proliferation

Cellular Movem
Morphology
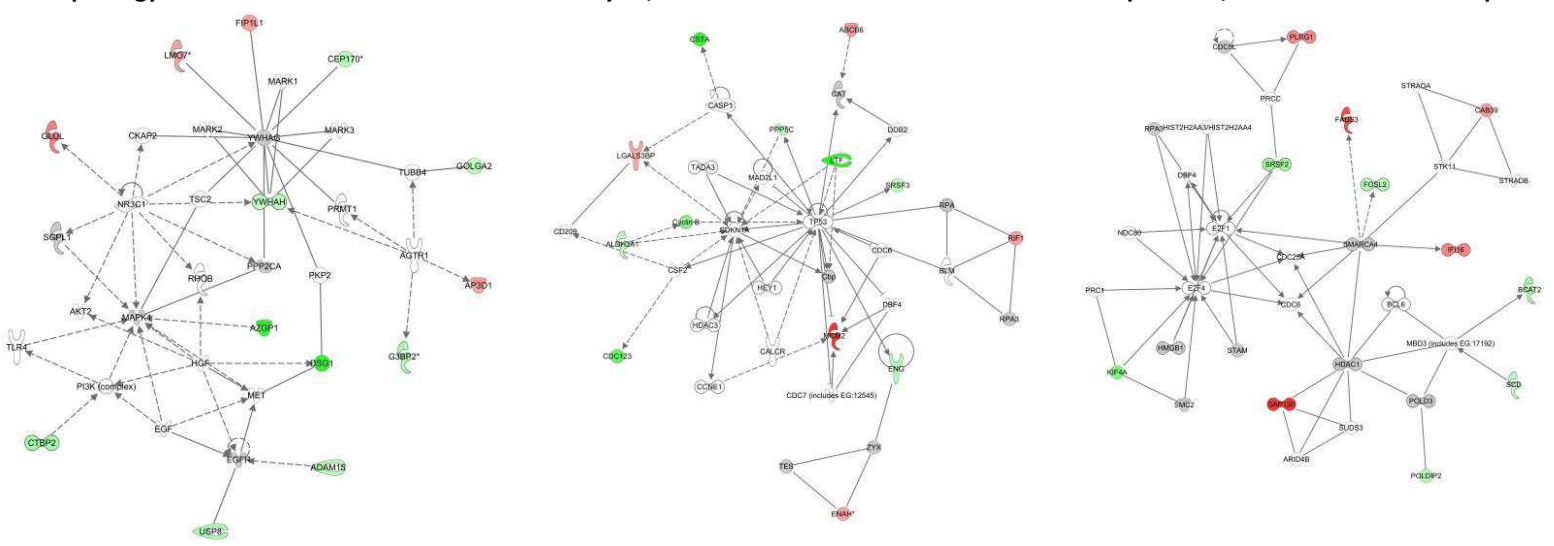

FIGURE 6 | Molecular pathways of regulated proteins. Proteins and their levels of regulation were imported into the Ingenuity Pathways Analysis $\left(\mathrm{PA}^{\oplus}\right)$ tool and interacting pathways were constructed. (A) Ontological classifications of all measured proteins (Total) as well as those significantly up- and down-regulated. The indicated ontological classifications start at the top of each pie chart and are presented clockwise. (B) Merged networks, containing all molecules present in each of the five individual networks. (C) The top five networks, identified at $95 \%$ confidence and each of which contained 11 or more "focus" molecules (molecules significantly up- or down-regulated), with pathway names indicated. Solid lines: direct known interactions; dashed lines: suspected or indirect interactions; red: significantly up-regulated proteins; pink: moderately up-regulated proteins; gray: proteins identified but not significantly regulated; light green: moderately down-regulated proteins; dark green: significantly down-regulated proteins; white: proteins known to be in network, but not identified in our study. 
Table 3 | Correlation and overlap between various sample preparation schemes.

\begin{tabular}{|c|c|c|c|c|c|c|}
\hline & $\begin{array}{l}\text { Cyto St vs. } \\
\text { Cyto PM }{ }^{1}\end{array}$ & $\begin{array}{l}\text { Nuc St vs. } \\
\text { Nuc PM }\end{array}$ & $\begin{array}{l}\text { Cyto St vs. } \\
\text { Nuc St }\end{array}$ & $\begin{array}{l}\text { Cyto PM vs. } \\
\text { Nuc PM }\end{array}$ & $\begin{array}{l}\text { Biological } \\
\text { replicate }^{2}\end{array}$ & $\begin{array}{l}\text { Technical } \\
\text { replicate }^{2}\end{array}$ \\
\hline Percentage of overlap & 73.7 & 67.9 & 65.4 & 68.0 & 67.3 & 81.5 \\
\hline Overall correlation $\left(r^{2}\right)$ & 0.444 & 0.255 & 0.159 & 0.606 & $0.038-0.057$ & 0.660 \\
\hline $\begin{array}{l}\text { Correlation }\left(r^{2}\right) \text { for up- and } \\
\text { down-regulated proteins only }\end{array}$ & 0.236 & 0.119 & 0.046 & 0.448 & $0.156-0.174$ & 0.414 \\
\hline
\end{tabular}

${ }^{1}$ Cyto, cytosolic fraction; Nuc, nuclear fraction; St, standard 2D-LC/MS; PM, Proteominer.

${ }^{2}$ Biological and technical values observed in another study Coombs et al. (2010); and unpublished.

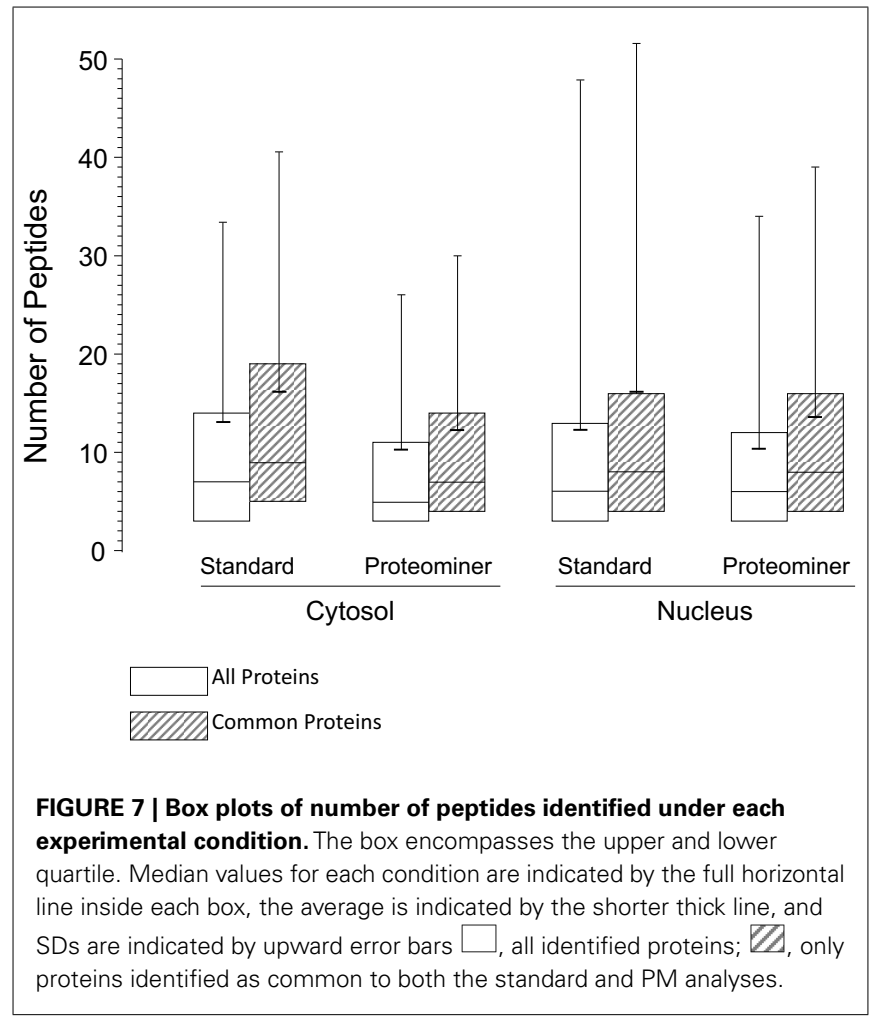

identified peptides, and the corresponding SD, were also lower in the PM-enriched fraction (Figure 7). This pattern was seen irrespective of whether all proteins were examined (white boxes), or only proteins common to both the standard and PM enrichment fractions (gray boxes). Previous studies in our lab have shown that biologic replicates have $\sim 67 \%$ overlap and an $r^{2}$ degree of

\section{REFERENCES}

Baas, T., Baskin, C. R., Diamond, D. L., Garcia-Sastre, A., BielefeldtOhmann, H., Tumpey, T. M., Thomas, M. J., Carter, V. S., Teal, T. H., Van Hoeven, N., Proll, S., Jacobs, J. M., Caldwell, Z. R., Gritsenko, M. A., Hukkanen, R. R., Camp, D. G. II, Smith, R. D., and Katze, M. G. (2006). Integrated molecular signature of disease: analysis of influenza virus-infected

correlation of about 0.04 , whereas technical replicates of the same biologic replicate have $\sim 82 \%$ overlap and an $r^{2}$ value of about 0.66 (Coombs et al., 2010; Table 3). Comparisons of the overlap and $r^{2}$ values between standard preparations and their cognate $\mathrm{PM}$ enrichment preparations showed intermediate values of $\sim 68$ $74 \%$ overlap and $r^{2}$ ranging between 0.25 and 0.44 (Table 3), suggesting the PM enrichment strategy did not add substantially to information provided by standard preparations.

\section{NOTE ADDED IN PROOF}

The Mann laboratory has recently used label-free approaches to determine the relative quantity of each of thousands of proteins in a variety of human cell lines, including HeLa cells (Geiger et al., 2012). As a more direct analysis to determine whether application of Proteominer beads led to identification of lower abundance proteins, we sorted our datasets and determined there were no significant differences in the average and median quantities of proteins identified by either of the two methods in each of the cytosolic and nuclear fractions, further strengthening the main conclusion of this study, that non-biased enrichment using this particular affinity method does not contribute to deeper proteomic mining.

\section{AUTHOR CONTRIBUTIONS}

Jieyuan Jiang and Kolawole J. Opanubi performed experimental work described herein, all co-authors performed database and computational analyses, and all co-authors wrote and edited the manuscript.

\section{ACKNOWLEDGMENTS}

This work was supported by grant MT-11630 from the Canadian Institutes of Health Research to Kevin M. Coombs. The authors thank Peyman Ezatti for expert technical assistance, and members of the laboratory for reviewing the manuscript.

for the identification of differentially expressed proteins following infection of Atlantic salmon (Salmo salar) with infectious hematopoietic necrosis virus (IHNV) or Renibacterium salmoninarum (BKD). J. Proteome Res. 4, 325-334.

Burgener, A., Boutilier, J., Wachihi, C., Kimani, J., Carpenter, M., Westmacott, G., Cheng, K., Ball, T. B., and Plummer, F. (2008). Identification of differentially expressed proteins in the cervical mucosa of HIV-1resistant sex workers. J. Proteome Res. 7, 4446-4454.

Coffey, M. C., Strong, J. E., Forsyth, P. A., and Lee, P. W. (1998). Reovirus therapy of tumors with activated Ras pathway. Science 282, 1332-1334.

Coombs, K. M. (2011). Quantitative proteomics of complex mixtures. Expert Rev. Proteomics 8, 659-677.

Coombs, K. M., Berard, A., Xu, W., Krokhin, O., Meng, X., Cortens, J. P., 
Kobasa, D., Wilkins, J., and Brown, E. G. (2010). Quantitative proteomic analyses of influenza virus-infected cultured human lung cells. J. Virol. 84, 10888-10906.

DeBiasi, R. L., Clarke, P., Meintzer, S., Jotte, R., Kleinschmidt-Demasters, B. K., Johnson, G. L., and Tyler, K. L. (2003). Reovirus-induced alteration in expression of apoptosis and DNA repair genes with potential roles in viral pathogenesis. J. Virol. 77, 8934-8947.

Dennis, G., Sherman, B. T., Hosack, D. A., Yang, J., Gao, W., Lane, H. C., and Lempicki, R. A. (2003). DAVID: Database for annotation, visualization, and integrated discovery. Genome Biol. 4. doi: 10.1186/gb2003-4-9-r60

Dwivedi, R. C., Dhindsa, N., Krokhin, O. V., Cortens, J., Wilkins, J. A., and ElGabalawy, H. S. (2009). The effects of infliximab therapy on the serum proteome of rheumatoid arthritis patients. Arthritis Res. Ther. 11. doi: $10.1186 /$ ar2637

Dwivedi, R. C., Spicer, V., Harder, M., Antonovici, M., Ens, W., Standing, K. G., Wilkins, J. A., and Krokhin, O. V. (2008). Practical implementation of 2D HPLC scheme with accurate peptide retention prediction in both dimensions for high-throughput bottomup proteomics. Anal. Chem. 80, 7036-7042.

Forsyth, P., Roldan, G., George, D., Wallace, C., Palmer, C. A., Morris, D., Cairncross, G., Matthews, M. V., Markert, J., Gillespie, Y., Coffey, M., Thompson, B., and Hamilton, M. (2008). A phase I trial of intratumoral administration of reovirus in patients with histologically confirmed recurrent malignant gliomas. Mol. Ther. 16, 627-632.

Geiger, T., Wehner, A., Schaab, C., Cox, J., and Mann M. (2012). Comparative proteomic analysis of eleven common cell lines reveals ubiquitous but varying expression of most proteins. Mol. Cell. Proteomics. PMID: 22278370. [Epub ahead of print].

Geiss, G. K., Salvatore, M., Tumpey, T. M., Carter, V. S., Wang, X. Y., Basler, C. F., Taubenberger, J. K., Bumgarner, R. E., Palese, P., Katze, M. G., and Garcia-Sastre, A. (2002). Cellular transcriptional profiling in influenza A virus-infected lung epithelial cells: the role of the nonstructural NS1 protein in the evasion of the host innate defense and its potential contribution to pandemic influenza. Proc. Natl. Acad. Sci. U.S.A. 99, 10736-10741.

Gilar, M., Olivova, P., Daly, A. E., and Gebler, J. C. (2005). Orthogonality of separation in two-dimensional liquid chromatography. Anal. Chem. 77, 6426-6434.

Goldberg, A. D., Allis, C. D., and Bernstein, E. (2007). Epigenetics: a landscape takes shape. Cell 128, 635-638.

Goody, R. J., Beckham, J. D., Rubtsova, K., and Tyler, K. L. (2007). JAKSTAT signaling pathways are activated in the brain following reovirus infection. J. Neurovirol. 13, 373-383.

Haller, O., and Kochs, G. (2002). Interferon-induced $\mathrm{mx}$ proteins: dynamin-like GTPases with antiviral activity. Traffic 3, 710-717.

Haller, O., Staeheli, P., and Kochs, G. (2009). Protective role of interferoninduced $\mathrm{Mx}$ GTPases against influenza viruses. Rev. Sci. Tech. 28, 219-231.

Huang, D. W., Sherman, B. T., and Lempicki, R. A. (2009a). Systematic and integrative analysis of large gene lists using DAVID bioinformatics resources. Nat. Protoc. 4, 44-57.

Huang, Q. L., Wang, L., Bai, S. Y., Lin, W. S., Chen, W. N., Lin, J. Y., and Lin, X. (2009b). Global proteome analysis of hepatitis B virus expressing human hepatoblastoma cell line HepG2. J. Med. Virol. 81, 1539-1550.

Jiang, J., Parker, C. E., Fuller, J. R., Kawula, T. H., and Borchers, C. H. (2007). An immunoaffinity tandem mass spectrometry (iMALDI) assay for detection of Francisella tularensis. Anal. Chim. Acta 605, 70-79.

Keshamouni, V. G., Jagtap, P., Michailidis, G., Strahler, J. R., Kuick, R., Reka, A. K., Papoulias, P., Krishnapuram, R., Srirangam, A., Standiford, T. J., Andrews, P. C., and Omenn, G. S. (2009). Temporal quantitative proteomics by iTRAQ 2D-LC-MS/MS and corresponding mRNA expression analysis identify post-transcriptional modulation of actin-cytoskeleton regulators during TGF-beta-Induced epithelialmesenchymal transition. J. Proteome Res. 8, 35-47.

Kobasa, D., Jones, S. M., Shinya, K., Kash, J. C., Copps, J., Ebihara, H., Hatta, Y., Kim, J. H., Halfmann, P., Hatta, M., Feldmann, F., Alimonti, J. B., Fernando, L., Li, Y., Katze, M. G., Feldmann, H., and Kawaoka, Y. (2007). Aberrant innate immune response in lethal infection of macaques with the 1918 influenza virus. Nature 445, 319-323.

Lucitt, M. B., Price, T. S., Pizarro, A., Wu, W., Yocum, A. K., Seiler, C., Pack, M. A., Blair, I. A., Fitzgerald, G. A., and Grosser, T. (2008). Analysis of the zebrafish proteome during embryonic development. Mol. Cell Proteomics 7, 981-994.

Mendez, II, Hermann, L. L., Hazelton, P. R., and Coombs, K. M. (2000). A comparative analysis of freon substitutes in the purification of reovirus and calicivirus. J. Virol. Methods 90, 59-67.

Pan, D., Pan, L. Z., Hill, R., Marcato, P., Shmulevitz, M., Vassilev, L. T., and Lee, P. W. K. (2011). Stabilisation of p53 enhances reovirus-induced apoptosis and virus spread through p53-dependent NF-kappa B activation. Br. J. Cancer 105, 1012-1022.

Poggioli, G. J., DeBiasi, R. L., Bickel, R., Jotte, R., Spalding, A., Johnson, G. L., and Tyler, K. L. (2002). Reovirusinduced alterations in gene expression related to cell cycle regulation. J. Virol. 76, 2585-2594.

Schiff, L. A., Nibert, M. L., and Tyler, K. L. (2007). "Orthoreoviruses and their replication," in Fields Virology, Vol. 5, eds D. M. Knipe and P. M. Howley (Philadelphia: Lippincott Williams \& Wilkins), 1853-1915.

Sherry, B. (2009). Rotavirus and reovirus modulation of the interferon response. J. Interferon Cytokine Res. 29, 559-567.

Skiba, M., Mettenleiter, T. C., and Karger, A. (2008). Quantitative whole-cell proteome analysis of pseudorabies virus-infected cells. $J$. Virol. 82, 9689-9699.

Smith, R. E., Zweerink, H. J., and Joklik, W. K. (1969). Polypeptide components of virions, top component and cores of reovirus type 3. Virology 39, 791-810.

Spicer, V., Yamchuk, A., Cortens, J., Sousa, S., Ens, W., Standing, K. G., Wilkins, J. A., and Krokhin, O. (2007). Sequence-specific retention calculator. A family of peptide retention time prediction algorithms in reversed-phase HPLC: applicability to various chromatographic conditions and columns. Anal. Chem. 79, 8762-8768.

Stewart, J. J., White, J. T., Yan, X., Collins, S., Drescher, C. W., Urban, N. D., Hood, L., and Lin, B. (2006). Proteins associated with Cisplatin resistance in ovarian cancer cells identified by quantitative proteomic technology and integrated with mRNA expression levels. Mol. Cell Proteomics 5, 433-443.

Thirukkumaran, C. M., Nodwell, M. J., Hirasawa, K., Shi, Z. Q., Diaz, R., Luider, J., Johnston, R. N., Forsyth, P. A., Magliocco, A. M., Lee, P., Nishikawa, S., Donnelly, B., Coffey, M., Trpkov, K., Fonseca, K., Spurrell, J., and Morris, D. G. (2010). Oncolytic viral therapy for prostate cancer: efficacy of reovirus as a biological therapeutic. Cancer Res. 70, 2435-2444.

Tian, Q., Stepaniants, S. B., Mao, M., Weng, L., Feetham, M. C., Doyle, M. J., Yi, E. C., Dai, H., Thorsson, V., Eng, J., Goodlett, D., Berger, J. P., Gunter,
B., Linseley, P. S., Stoughton, R. B., Aebersold, R., Collins, S. J., Hanlon, W. A., and Hood, L. E. (2004). Integrated genomic and proteomic analyses of gene expression in mammalian cells. Mol. Cell Proteomics 3, 960-969.

Tran, A. T., and Coombs, K. M. (2006). "Reoviruses," in Encyclopedia of Life Sciences, Vol. 2. (Elsevier). doi: 10.1038/npg.els.0004289

Vester, D., Rapp, E., Gade, D., Genzel, Y., and Reichl, U. (2009). Quantitative analysis of cellular proteome alterations in human influenza A virusinfected mammalian cell lines. Proteomics 9, 3316-3327.

Zhang, J., Niu, D., Sui, J., Ching, C. B., and Chen, W. N. (2009). Protein profile in hepatitis B virus replicating rat primary hepatocytes and HepG2 cells by iTRAQ-coupled 2-D LC-MS/MS analysis: insights on liver angiogenesis. Proteomics 9, 2836-2845.

Zolotarjova, N., Mrozinski, P., Chen, H., and Martosella, J. (2008). Combination of affinity depletion of abundant proteins and reversed-phase fractionation in proteomic analysis of human plasma/serum. J. Chromatogr. A 1189, 332-338.

Zurney, J., Kobayashi, T., Holm, G. H., Dermody, T. S., and Sherry, B. (2009). Reovirus mu2 protein inhibits interferon signaling through a novel mechanism involving nuclear accumulation of interferon regulatory factor 9. J. Virol. 83, 2178-2187.

Conflict of Interest Statement: The authors declare that the research was conducted in the absence of any commercial or financial relationships that could be construed as a potential conflict of interest.

Received: 17 May 2012; accepted: 06 August 2012; published online: 20 September 2012

Citation: Jiang J, Opanubi KJ and Coombs KM (2012) Non-biased enrichment does not improve quantitative proteomic delineation of reovirus T3D-infected HeLa cell protein alterations. Front. Microbio. 3:310. doi: 10.3389/fmicb.2012.00310

This article was submitted to Frontiers in Virology, a specialty of Frontiers in Microbiology.

Copyright @ 2012 Jiang, Opanubi and Coombs. This is an open-access article distributed under the terms of the Creative Commons Attribution License, which permits use, distribution and reproduction in other forums, provided the original authors and source are credited and subject to any copyright notices concerning any third-party graphics etc. 